\title{
Historical Ecologies of Pastoralist Overgrazing in Kenya: Long-Term Perspectives on Cause and Effect
}

\author{
Oliver J. C. Boles ${ }^{1,2,3}$ (D) Anna Shoemaker ${ }^{4} \cdot$ Colin J. Courtney Mustaphi ${ }^{2,4,5} \cdot$ Nik Petek $^{4} \cdot$ Anneli Ekblom $^{4}$. \\ Paul J. Lane ${ }^{4,6,7}$
}

Published online: 18 May 2019

(C) The Author(s) 2019

\begin{abstract}
The spectre of 'overgrazing' looms large in historical and political narratives of ecological degradation in savannah ecosystems. While pastoral exploitation is a conspicuous driver of landscape variability and modification, assumptions that such change is inevitable or necessarily negative deserve to be continuously evaluated and challenged. With reference to three case studies from Kenya - the Laikipia Plateau, the Lake Baringo basin, and the Amboseli ecosystem - we argue that the impacts of pastoralism are contingent on the diachronic interactions of locally specific environmental, political, and cultural conditions. The impacts of the compression of rangelands and restrictions on herd mobility driven by misguided conservation and economic policies are emphasised over outdated notions of pastoralist inefficiency. We review the application of 'overgrazing' in interpretations of the archaeological record and assess its relevance for how we interpret past socio-environmental dynamics. Any discussion of overgrazing, or any form of human-environment interaction, must acknowledge spatio-temporal context and account for historical variability in landscape ontogenies.
\end{abstract}

Keywords Historical ecology · Compression effects · Rangeland management · Pastoralist mobility strategies · Eastern Africa · Kenya

\section{Introduction}

As Europeans pushed to colonize and cultivate lands in the intemperate tropics they became intensely interested in the

Oliver J. C. Boles

oboles@sas.upenn.edu

1 Department of Anthropology, University of Pennsylvania, Philadelphia, PA, USA

2 York Institute for Tropical Ecosystems, Environment Department, University of York, York, UK

3 Institute of Archaeology, University College London (UCL), London, UK

4 Department of Archaeology and Ancient History, Uppsala Universitet, Uppsala, Sweden

5 Geoecology, Department of Environmental Science, University of Basel, Basel, Switzerland

6 Department of Archaeology, University of Cambridge, Downing Street, Cambridge, UK

7 School of Geography, Archaeology and Environmental Studies, University of the Witwatersrand, Johannesburg, South Africa relationships among deforestation, rainfall, soil erosion, and desertification (Grove 1996; Davis 2004). Eighteenth- and nineteenth-century observers linked the practices of indigenous communities with landscape degradation and loss of productivity. In North Africa, for instance, French settlers' belief that the Maghreb had once been 'the abundant granary of Rome' (Perier 1847: 29), stripped of its productivity over centuries of misuse by nomadic pastoralists, was used to justify policies of land appropriation and forced-sedentarization (Davis 2004). This vilification of herders was widespread across the continent throughout the colonial era, supported by academic theorising. The 'cattle complex' as constructed by Herskovits (1926), framed pastoralists as constantly and irrationally seeking to accumulate livestock with little regard for efficiency or sustainability (c f. Livingstone 1991) and was emblematic of attitudes in academic and political circles. Stock-keepers were perpetrators of the 'tragedy of the commons' (Hardin 1968) wherein commonly-held land would invariably be maximally exploited by individuals to the detriment of the collective good. These ideas were at the core of land management policy in colonial eastern Africa, and pastoralist inefficiency was viewed as anathema to productivity. For example, the Chief Agricultural Officer in colonial Kenya 
during the 1950s considered the predominance of milk-based economies over meat-oriented production, deemed more efficient in terms of food provision per unit of forage, to be a demonstration of pastoralists' irrationality. He believed overstocking was an unavoidable consequence (Brown 1971).

Since the mid-1980s, more sophisticated understandings of the drivers of land degradation have emerged. These approaches apply new models of nonequilibrium ecosystem dynamics and awareness of the effects of long-term climatic variability, emphasising the incorporation of local knowledge into land use management and recognising the potential ecological benefits of pastoralist settlement and grazing regimes (Homewood 2008; Reid 2012). There is also growing recognition (e.g., Blake et al. 2018) that contrasting disciplinary perspectives, and information and implementation gaps between different stakeholders, can combine to limit the uptake of alternative approaches to land management by governments and pastoralists, resulting in the exacerbation of pressures leading to overgrazing. Notwithstanding these developments, established narratives of overgrazing still haunt recent discussions of current degradation and its drivers in Africa in both academic (e.g., Hein 2006) and public discourse (Shanahan 2016), and in many parts of the African continent continue to shape policy interventions (e.g., Gilbert 2013). These arguments have also resurfaced in broader studies concerning the antiquity of the Anthropocene (e.g., Zerboni and Nicoll 2018) and in interpretations of the drivers of palaeoenvironmental change (e.g., Wright 2017; for a counter argument see Brierley et al. 2018).

Overgrazing and attendant changes to land are certainly important issues that have significant consequences for rural livelihoods and the vulnerability of pastoralist communities to a variety of risks. However, understanding the connections between different agents and processes demands nuanced, evidence-based analyses rather than a priori generalisation. This is well illustrated by a series of recent studies of transformations in the nature of land holding and access in semi-arid areas of Kenya over recent decades, where privatization of former commons has not progressed in a simple linear fashion as often predicted by common theories of property evolution (Galaty 2016), and even in the context of privatized land pastoralists often seek to recreate social relations that are more characteristic of the commons (Archambault 2016). In a similar vein and with reference to some of these same areas, we argue in this paper that the impacts of livestock on African ecosystems are highly variable and contingent on particular political, social, and environmental context. To account for the diverse drivers of ecological change, analysis requires not only a longer temporal perspective, spanning decadal-to-millennial scales, but must be informed by multiple modes of enquiry. Here, we discuss the historical and ecological trajectories of pastoralism in three case studies in central areas of Kenya (Fig. 1). These three ecosystems - Laikipia, Baringo and Amboseli - have featured

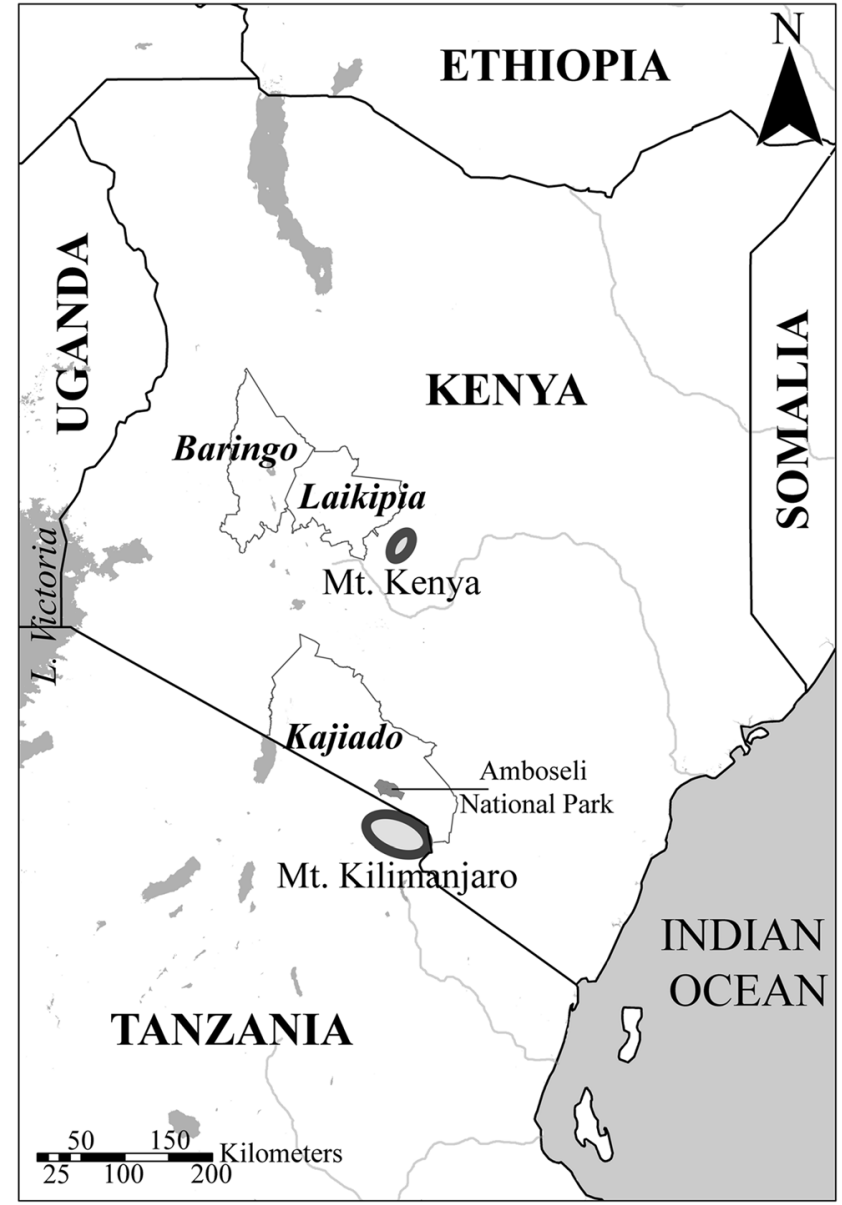

Fig. 1 Map of eastern Africa showing the three case study regions and other key locations

frequently in debates on conservation, sustainability, changing relationships between agriculturalists and herders, and the landscape-transformative potential of pastoralism for over seven decades. Each ecosystem has been subject to active intervention by governing authorities based on now-outdated paradigms in ecological theory. However, the removal of pastoralists from a landscape is not simply equivalent to the removal of livestock; centuries of anthropogenic fire regimes, for example, instituted by herders in order to influence rangeland productivity, have shaped savannahs as decisively as the nutrient re-distributive capacities of grazing animals. Landscape histories must therefore be understood with reference to the longue durée of human interaction. With this point in mind, we consider how the complex ontogenies of pastoral landscapes can be explored given the limitations of archaeological and palaeoenvironmental records in terms of their spatial and temporal resolution.

\section{Case Study 1: Laikipia}

The high-elevation rangelands of the Laikipia Plateau lie at the transition between the fertile, agricultural highlands of southern 
Kenya and the drier plains of the north and have hosted pastoralist economies for several millennia. Dates from Ol Ngoroi rockshelter in the Lolldaiga Hills indicate that domesticates have been present in Laikipia since the fifth millennium BP, among the earliest such dates south of Ethiopia (Lane 2015). This presence continued throughout the Pastoral Neolithic and Pastoral Iron Age (Lane 2011; Boles and Lane 2016).

In the early twentieth century, following multi-year droughts and disease epidemics (e.g., rinderpest) that had decimated livestock numbers across eastern Africa (Waller 1988), the Laikipia region was designated the 'Northern Maasai Reserve' by the colonial administration. The proclamation of the reserve facilitated colonial appropriation of prime grazing and farming resources in the Central Rift Valley and the highlands around Nairobi. However, the reserve was withdrawn in 1911 following an agreement - now contested - between the British and certain Maasai leaders. Laikipia was apportioned for European holdings, and African pastoralists along with some one million sheep and 200,000 cattle were moved to the 'Southern Reserve' near the border with German East Africa (now Tanzania) (Hughes 2006). Delayed by the outbreak of the First World War, by the 1920s much of the region's productive land was appropriated through soldier settlement schemes. Nonetheless, vast empty areas remained and by the 1930s many potential farmers were declining to settle, citing the poor quality of the often-water-deprived soil. Issue was also taken with the size of the holdings available, which were normally in the region of 1000-5000 acres; a viable livestock farm was widely considered to require upwards of 15,000 acres. However, various processes whereby unoccupied land could be leased during periods of drought as well as a relaxed approach towards ranchers exceeding the limits of their licensed lands ensured that European control persisted throughout the colonial period (Vaughan 2005).

While the process of 'Africanisation' that followed Kenya's independence in 1963 led to the sale and division of certain ranches, over half remained under European ownership in the early-twenty-first century (Wambuguh 2007). Presently, many properties maintain some commercial livestock operations, often alongside interests in wildlife ecotourism, while others are now dedicated to conservation. Other land is designated for community ownership in the form of 'group ranches,' and many properties in the southern part of the plateau were subdivided around independence for smallscale farming by communities from the densely-populated former Kikuyu Tribal Reserve (Köhler 1987). The long-term prospects of these farms are unclear; however, of the $8.4 \%$ of the district already under cultivation only $1.7 \%$ is considered to have high agricultural potential (Huber and Opondo 1995).

Inequalities in land ownership in Laikipia are stark. Since the mid-1960s the population rose from around 60,000 to over half a million by the early twenty-first century, yet around $40 \%$ of the district is controlled by 48 wealthy individuals
(Letai 2011). The number of cattle in Laikipia is thought to be in the region of 200,000 and sheep and goats nearly half a million (2011-2013 estimates, Ogutu et al. 2016). Importantly, though these numbers are similar to pretwentieth century levels (Hughes 2006), there has been a significant contraction of rangelands since the expansion of agriculture in the verdant southern plateau. Furthermore, low stock-densities within the private conservancies mean that community ranches bear the greatest burden. The larger private ranches can generally afford to operate within their carrying capacities and, indeed, such surplus is vital to their success as wildlife reserves (e.g., Mizutani 1999). These relatively economically-secure enterprises can afford to be flexible with regard to their intensity of production (Sundaresan and Riginos 2010) - for example, cessation of milk production during drought (Mizutani 1999). The community ranches are mainly located in the drier northern part of the plateau (Letai 2011) and host livestock numbers that often exceed recommendations (Sundaresan and Riginos 2010).

Over two decades ago Livingstone (1991: 81) made the point that although the group ranches can be said to be 'overstocked' in terms of an observed year-on-year reduction in available herbage, average household livestock holdings are considerably below that required for subsistence, as documented among the Mukogodo Maasai in eastern Laikipia. While in some areas arrangements with landowners allow local pastoralists controlled-access to grazing and water within the private ranches, land invasion is an ongoing problem and Laikipia has garnered notoriety in the international media following the murders of several European ranchers, Kenyan rangers, and police reservists over recent years. These invasions can bring tens of thousands of cattle into the ranches with dramatic impacts on local ecologies and though usually associated with periods of drought (e.g., 2011-12 and 201617), their motivations cannot be divorced from political context (Iaccino 2017). Tensions arising from efforts to conserve and protect Laikipia's elephant populations, including debates over the need for, and contributions of, fencing (Bond 2015; Evans and Adams 2016), further complicate the situation. As noted by Galaty (2016: 717), in some parts of Laikipia over the last decade or so, and as a consequence of these frictions, 'land has gone through a transition, from being managed as private holdings - both large and small-scale - through a stage of 'open access' as owners have 'abandoned' them, to being relatively stable common holdings, governed by the pastoralists who have moved in and asserted rights.' The rules governing access to grazing land are also changing, with the significance of older practices based on traditions of reciprocity diminishing, and an increased emphasis on rights being acquired through membership of formal, territory-based institutions (such as group ranches or community conservancies). This has had a number of spatial and temporal consequences for mobility patterns that can further exacerbate lines of 
conflict between pastoralists and other land users in Laikipia (Pas Schrijver 2019).

At the same time as rangelands are divided, the population of Laikipia is increasingly sedentary. Besides the growing importance of agriculture in the southern part of the plateau, this can be linked to the influx of small-holder farmers from adjacent counties. Recent decades have also brought a trend towards sedentism on the part of formerly peripatetic herders, with many males abandoning herding in favour of employment on private ranches as professional stockmen and wildlife rangers (Yurco 2017). High rainfall associated with a strong El Niño-Southern Oscillation in 1997-1998 saw many pastoralists establish permanent settlements in the Mukogodo area of eastern Laikipia (Strum et al. 2015). Livestock are now perennially present where herders previously moved seasonally in accordance with grazing conditions (e.g., Huho et al. 2010). The ecological consequences of this are palpable: for example, the introduced invasive Opuntia stricta (prickly pear), a stress-tolerant species that thrives in degraded semi-arid environments, has spread throughout the ranches (Strum et al. 2015), reducing available pasture. Mechanical removal is time consuming and difficult, while biological controls, such as introduced beetles, have proven ineffective (Paterson et al. 2011). Notably, although O. stricta is also present in the adjacent Lolldaiga Hills Ranch - a privatelymanaged $200 \mathrm{~km}^{2}$ ranch and wildlife conservancy - it is found in much lower densities. At Lolldaiga, grazing is managed according to a seasonal rotation between the hills in the southern part of the property and the plains in the north, such that no single pasture is subject to the perennial grazing that Strum et al. (2015) assert to be the principal degrading factor in Mukogodo (Fig. 2). Indeed, Taiti's (1992) claim that

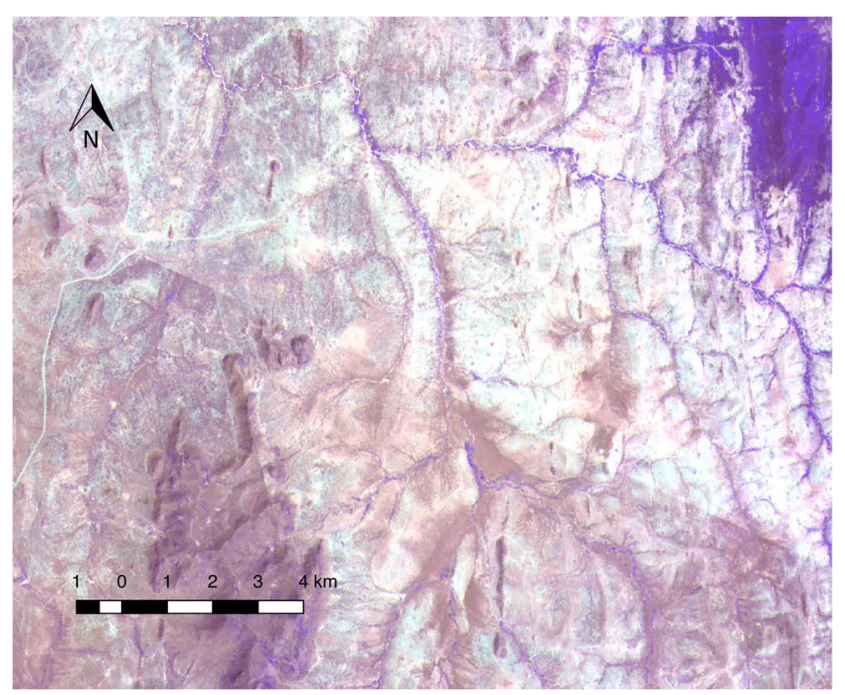

Fig. 2 ASTER L1B satellite image showing the boundary line between the privately-owned Lolldaiga Hills Ranch (bottom half of image) and the Mukogodo Group Ranch (top half). Note the paler colouring north of the fence depicting much-reduced grass cover herding in Laikipia exerted no 'traumatic influence' prior to 1960 - at which point Kenyan national independence heralded a population boom and a reduction of pastoral mobility - is supported by the example of the Lolldaiga Hills Ranch, where stock numbers and management practices have seen little demonstrable intensification since the early twentieth century (Mizutani 1999).

\section{Case Study 2: Baringo}

The Lake Baringo basin lies immediately to the west of the Laikipia Plateau, extending over $6200 \mathrm{~km}^{2}$ along the Rift Valley, and is characterised by bare soils, severe erosion, and invasive plants (Bessems et al. 2008; Becker et al. 2016). Though herding has been the dominant subsistence strategy for the past 3000 years, the intensity of pastoral occupation has fluctuated; this is apparent in the large number of sites associated with Pastoral Neolithic Turkwel ceramics (c. 200$1100 \mathrm{AD}$ ) coeval with a more arid period in the Lake Bogoria basin, and an almost complete lack of Pastoral Iron Age sites (c. 900-1700 AD) during the wetter Little Ice Age (c. 1250-1750) (Ashley et al. 2004; De Cort et al. 2013; Petek 2018). The form of agro-pastoralism practiced by the Ilchamus and Tugen people was established in the Baringo basin and surrounding areas in the late nineteenth century (Anderson 2002), and Pokot, Samburu, and Maasai pastoralists have been present in the region since at least the 1800s (Bollig 2016), at which point the climate was considerably drier.

Narratives of pastoral overgrazing in Baringo emerged during the severe droughts and locust infestations of the 1920s, when colonial officials began to question why the region, once famous as a granary due to its irrigated field systems, could not sustain its own population (Anderson 2002; Petek and Lane 2017). The notion that Baringo could be restored to a prior fertility was propagated in the following decades during deliberations about the expansion of the native reserve and developments such as the Perkerra Irrigation Scheme (Kramm 2015). Begun in 1952, this initiative was intended to feed the inhabitants of Baringo through grain cultivation and provide income through the export of cash crops, enticing people away from herding. However, the scheme incurred huge financial losses and was insufficiently productive to meet local needs (Kramm 2015).

Baringo is generally a dry region marked by a high interannual variability in rainfall, and early colonial maps describe vegetation in the lake basin as thornbush or shrub with rare grasses (Fig. 3). European explorers also remarked on barren lands and dust storms (Thomson 1885; von Höhnel 1892), indicating that the area might not have been as productive as reported in second-hand accounts written during the late 1800s. Some doubt existed during colonial times about the imagined past verdancy of the basin (Little 1992: 47; 
Fig. 3 Colonial maps with vegetation descriptions showing Lake Baringo and Laikipia. a map of the Expedition made by the East Africa Syndicate Ltd. from November 181,902 to March 41,903 (map\# WOMATAFR-BEA-92 held by the British Library); b Map of Masailand (map\# WOMAT-AFR-BEA-41 held by the British Library)
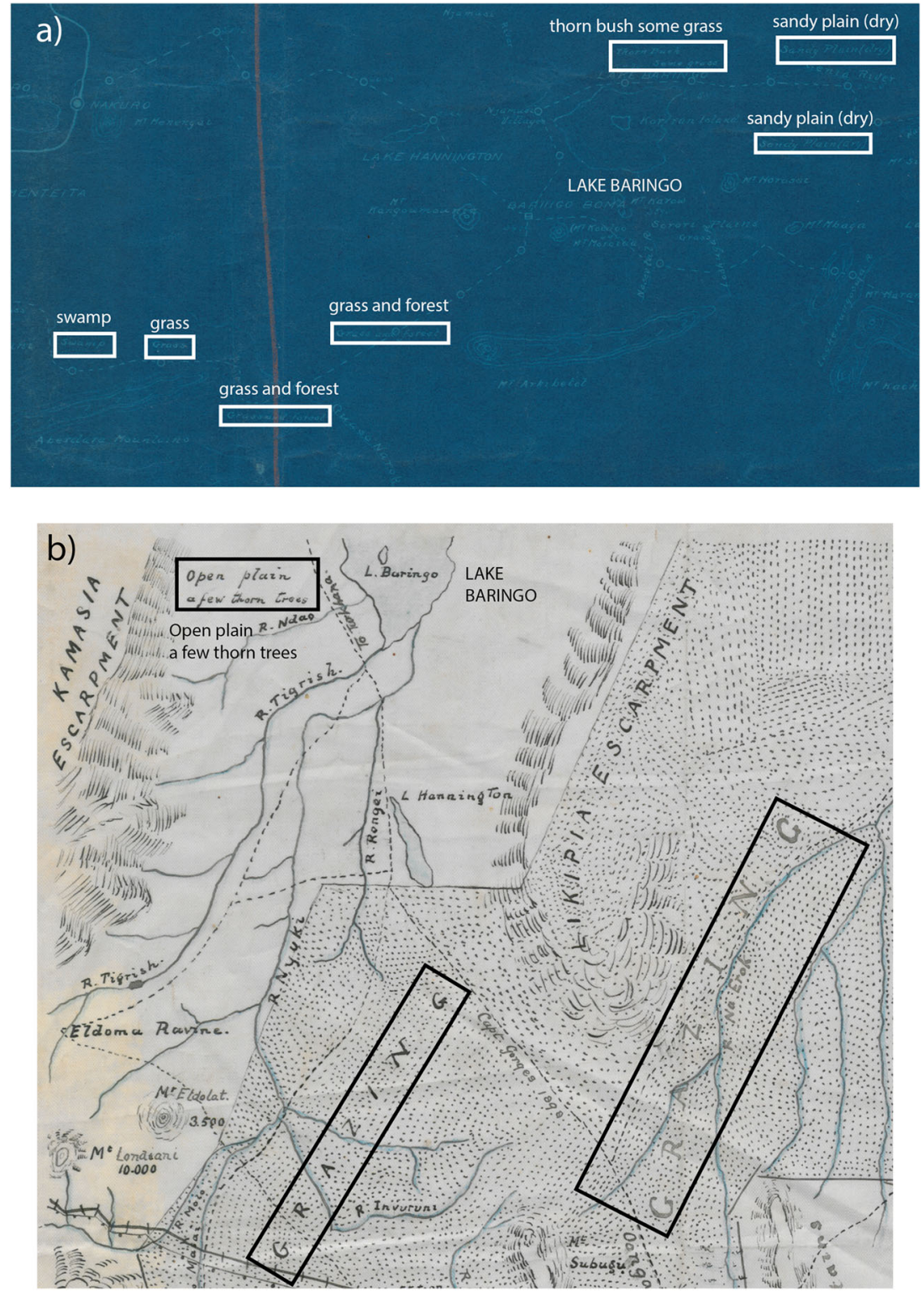

Anderson 2002: 231), and it remains to be established how natural and anthropogenic factors interplayed to form the precolonial woodland savanna. Soils in semi-arid regions regularly experience high erosion even without human influence (Dunne et al. 1978: 131), and in Baringo are especially prone to erosion by wind and water due to a silty, poorly-developed and powdery structure, high sodium levels that preclude water infiltration, and low organic matter content derived from scarce and rapidly decomposing vegetation (Republic of Kenya 1984; Kiage 2013). Sedimentary evidence shows increased terrestrial sediments being deposited into Lake Bogoria in recent decades linked to anthropogenic soil erosion in the watershed (de Cort et al. 2018).

The consequences of colonial intervention in Baringo included reduced social mobility between ethnic communities, discouragement of interethnic communication, as well as inhibited access to pastures controlled by other communities where access could previously be negotiated (Little 1992; Anderson 2002; Bollig and Österle 2013). Externallyimposed boundaries and decreased mobility made grass a contested resource. Access to it had to be controlled and pasture allocated for either wet or dry season grazing (Bollig and Österle 2013). With the establishment of group ranches, large numbers of livestock were present in varying densities within a fragmented landscape that experiences decadal-scale droughts and sporadic rains. Little movement was allowed beyond designated boundaries, resulting in enduring damage to some of the most intensively-grazed areas (Anderson 2002; Anderson and Bollig 2016). Fire setting, used by pastoralist communities to suppress woody plant growth and create or 
maintain pastures, was forbidden in Baringo under colonial rule and controlled burns eventually diminished (Vehrs and Heller 2017).

Wildlife too played an important role in keeping the landscape open, alongside domestic livestock and fire. Early European explorers and colonial officials describe large herds of buffalo, wildebeest, zebra, and other grazers and browsers, including elephant and rhinoceros (Thomson 1885; von Höhnel 1892; Dundas 1910). At the beginning of the twentieth century, Baringo was popular with sport hunters, which brought in considerable revenue at the expense of significant reductions in game animals (Powell-Cotton 1904; Chapman 1908). Limited resources also exacerbated human-wildlife conflict and large wild mammals in Baringo were nearly extirpated by the late 1940s (Little 1996). Defaunation contributed to the disappearance of grasses and the encroachment of the bushes and acacia trees that now dominate the landscape (Vehrs and Heller 2017). Pollen records from nearby Lake Bogoria show an ongoing decrease in grasses from c. 50\% of the record in c. 1910 to $18 \%$ in the past decades and an expanding woodland component associated with acacias, Amaranthaceae and Asteraceae (van der Plas et al. in review). Remote sensing data show that the initially dispersed settlements of the early twentieth century also become more concentrated at specific centres around grass-rich swamps as pastures diminished, more land was put aside for farming, and people became more sedentary (Petek 2018). Although the population has continued to grow, livestock numbers have stagnated since the mid-twentieth century and many farms are not economically viable or able to support households (Little 1992; Anderson 2002) as a consequence of the continued application of colonial policies even after independence.

\section{Case Study 3: Amboseli}

The Amboseli ecosystem is centred on a $600 \mathrm{~km}^{2}$ palaeolake basin in Kajiado County, south-eastern Kenya, with a further nearly $8500 \mathrm{~km}^{2}$ of rangelands utilized seasonally by migratory wildlife. The area includes the Amboseli National Park and its spring-fed wetlands, charged by orographic precipitation onto nearby Mount Kilimanjaro. These perennial wetlands have persisted throughout the late Holocene (Githumbi et al. 2018a, b) and provide water and pasture to a diverse community of large mammals, including livestock (Western 1975). Archaeological research in Amboseli suggests that livestock herding has been practiced since the Pastoral Neolithic, with conclusive evidence dating to the Iron Age (Shoemaker 2018). Stock keeping remains a major livelihood component for many households in the region, often in combination with agriculture and ecotourism (BurnSilver 2009; Homewood et al. 2012).
State-led initiatives to manage water and land resources for wildlife have a long history in Amboseli, beginning at the onset of the colonial period (Lindsay 1989). Early policy interventions identified Maasai-owned cattle, sheep, and goats as drivers of overgrazing, environmental degradation and desertification (Lewis 2015). Justification for gazetting a National Reserve in 1948 and the creation of Amboseli National Park in 1974 lay in part in the perceived need to safeguard water, pasture, and wildlife in the basin from threats posed by pastoralism. An overarching trend in the Amboseli ecosystem throughout the twentieth century was the adjudication and commodification of communal rangelands into parcels of ever-diminishing size, transformations often driven by the notion that privatisation would reduce overstocking and increase investments in ranching and agricultural production systems (Rutten 1992). The fragmentation of rangelands has had deleterious effects on pastoralists and wildlife alike, however, as rangeland subdivision and increased sedentarization have encouraged the forced concentration of grazing pressure around diminishing resources (Western et al. 2009; Groom and Western 2013). The negative effects of sedentarisation and subdivision are evident in a comparative study between a subdivided and unsubdivided group ranch in Amboseli, which found that despite livestock densities being equal, pasture was diminished on the subdivided ranch and the capacity for grass to regenerate after drought was more limited (Groom and Western 2013).

Parallels can be drawn between overgrazing caused by insularized and sedentary livestock and that associated with elephant populations in Amboseli (Fig. 4). A study by Western et al. (2015) has found a doubling in grazing pressure in Amboseli National Park between 1982 and 2010, concomitant with a long-term fall in biomass yield per unit of rainfall. Estimates of livestock and most wild migratory grazing herbivore populations in eastern Kajiado between 1977 and 2011 indicate their numbers have been falling, whereas the number of elephants is calculated to have increased by $115 \%$ (Ogutu et al. 2014). Elephants in Amboseli have also become less mobile since the mid-twentieth century due to a regional contraction in habitat and the threat of poaching (Moss 2001; Croze and Lindsay 2011: 27-28). Such a localized population increase is consequential, as elephants have significant impacts on vegetation structure and woody plant coverage (Morrison et al. 2016). Over the last half-century woodland and bushland vegetation zones within the National Park have been in sharp decline, and along with this loss of habitat diversity has been a decrease in large mammal diversity (Altmann 1998; Western and Maitumo 2004). This loss in biodiversity is linked to elephants seeking refuge in the park (owing to intensifying human presence and a regional contraction in habitat), where they have extensively grazed on acacia woodlands (Western and Maitumo 2004). During the dry season elephants in Amboseli shift their diets from grass toward 
Fig. 4 a Maasai settlement in Amboseli. Note the adjacent dark patch which marks the site of a previous settlement (Photo P. Lane); b Elephants crossing into Amboseli National Park (Photo A. Shoemaker)

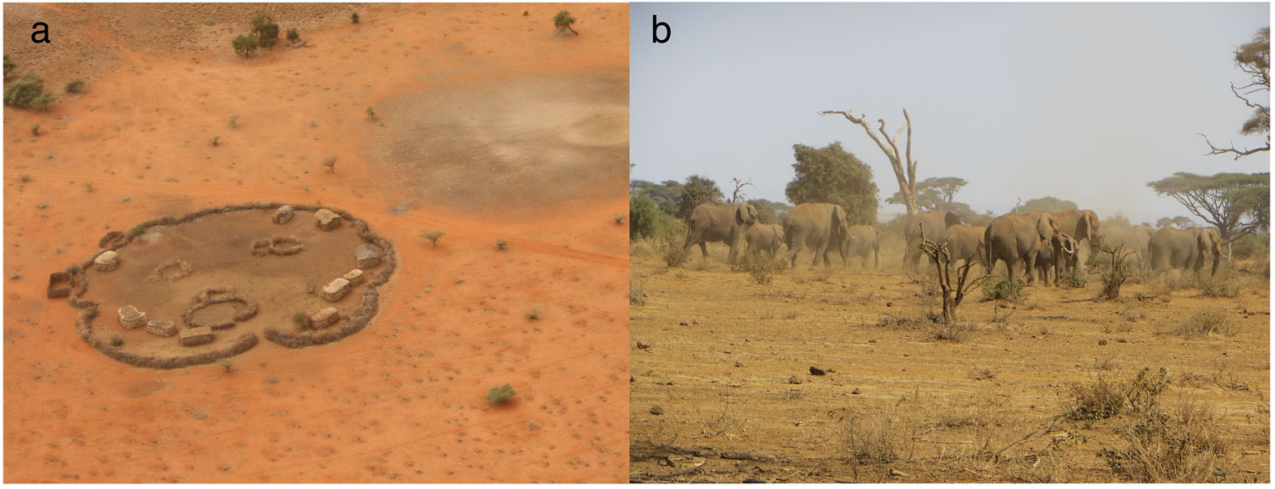

woody browse to enable them to better cope with the lack of pasture (Lindsay 2011: 68). In addition, the patchy distribution of water and woodlands in the arid and increasingly fragmented rangelands encourages elephants to cluster in high densities around vegetation and wetland refugia during periods of drought, depleting local forage resources (De Beer et al. 2006; Chamaillé-Jammes et al. 2008). As the mortality of trees has exceeded the recruitment of woody vegetation in the area, the landscape has become more open. The extent to which elephants are driving the contraction of woodlands in Amboseli remains contentious (see Spinage 2012), yet there is evidence in Amboseli indicating that as elephants are compressed into drought refugia, rangeland productivity declines (Western et al. 2015). In contrast, outside protected areas it is said that 'cattle create trees' (Reid 2012: 184). Here, the presence of humans to a large degree deters elephants from removing woody vegetation, and livestock grazing has been found to promote seedling growth by cropping the herbaceous layer and increasing space and access to light (Western and Maitumo 2004).

\section{Discussion}

The variety of approaches to land use policy and rangeland management employed in Laikipia, Baringo, and Amboseli, and the ecological consequences of these interventions with reference to overgrazing must be considered within the context of each area's colonial and post-colonial history, as we have shown here (Fig. 5). The disparity in resources between Laikipia's private and community ranches is reflected in the productivity and sustainability of their respective management strategies. Surplus resources within the private ranches ameliorate abiotic unpredictability in the form of climatic and environmental change, while overpopulated communal lands with restricted access to pastures are often inefficient and left vulnerable to drought and blight. In Baringo, landscape rehabilitation projects were based on a failure to comprehend the significant local hydroclimatic variability that makes the region suited to flexible and mobile stock-based production but not intensive agriculture. By limiting pastoralist mobility colonial authorities intended to prevent the degradation of potentially high-yield areas reserved for Europeans (Anderson 2002), yet these programmes alienated pastoralists from rangelands ill-suited to other forms of production. Amboseli has seen similar processes of rangeland fragmentation and a push from successive authorities towards sedentism, creating the conditions for overgrazing both on and off conservancies. It is also clear that degradation there may be partly attributed to mismanaged conservation strategies implemented in the early and mid-twentieth century. In all cases, landscape change, degradative or otherwise, is fundamentally a product of particular historical and socio-political conditions as opposed to being an inevitable outcome of pastoral production.

\section{Maintaining 'Balance'}

As well exemplified in Baringo, the mismanagement of eastern African rangelands stems from widespread misunderstandings of the dynamic variability of water and grazing resources, and a lack of awareness of the strategies pastoralists employ to navigate this variability. Non-equilibrium ecological theory highlights the environmental stochasticism seen in many semi-arid landscapes and cites variability as the principal driver of ecological persistence (Ellis and Swift 1988). In grazing systems with predictable rainfall and forage (so-called equilibrial systems), livestock populations are moderated by competition, and conservative stocking rates are encouraged so that pasture shortages during dry years do not bring drastic drought-induced mortality (Caughley 1979). However, in grazing systems where forage production is unpredictable and variable (non-equilibrium systems), competition over resources features minimally in regulating populations (Wiens 1977; Ellis and Swift 1988). It has been suggested that biotic factors like grazing have no lasting impact in systems where inter-annual rainfall varies by a coefficient of $>30 \%$ (Stafford Smith 1996). Under such conditions, livestock populations are 
Fig. 5 Conceptual table summarising: a) theoretical developments in rangeland ecology and their relevance and application; b) the causal relationships between historical interventions and ecological modification and degradation in our case study areas

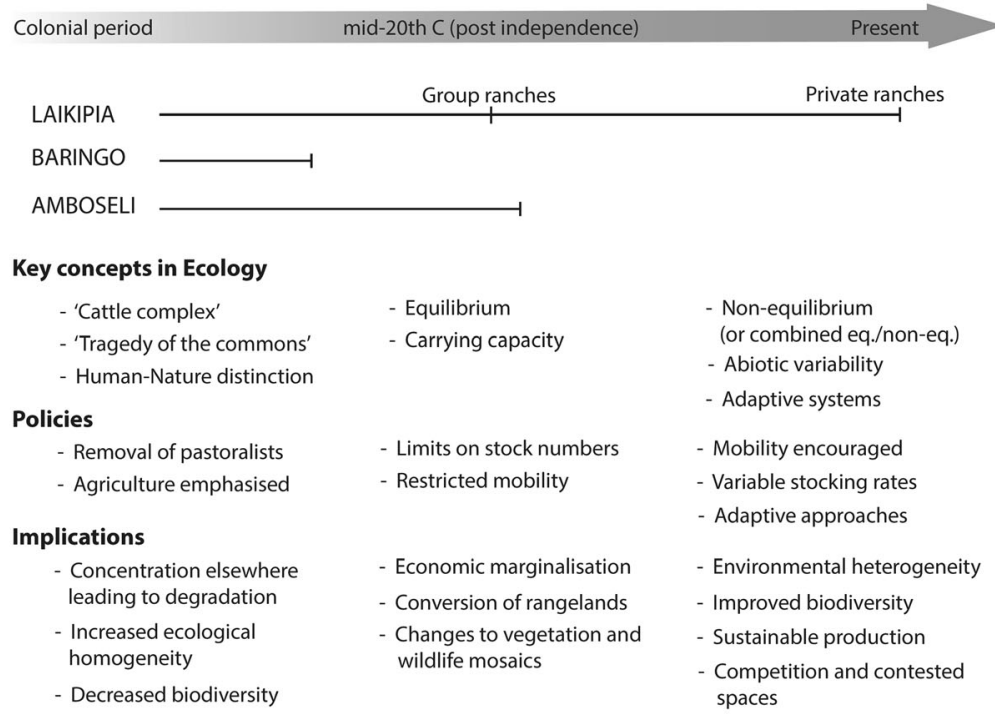

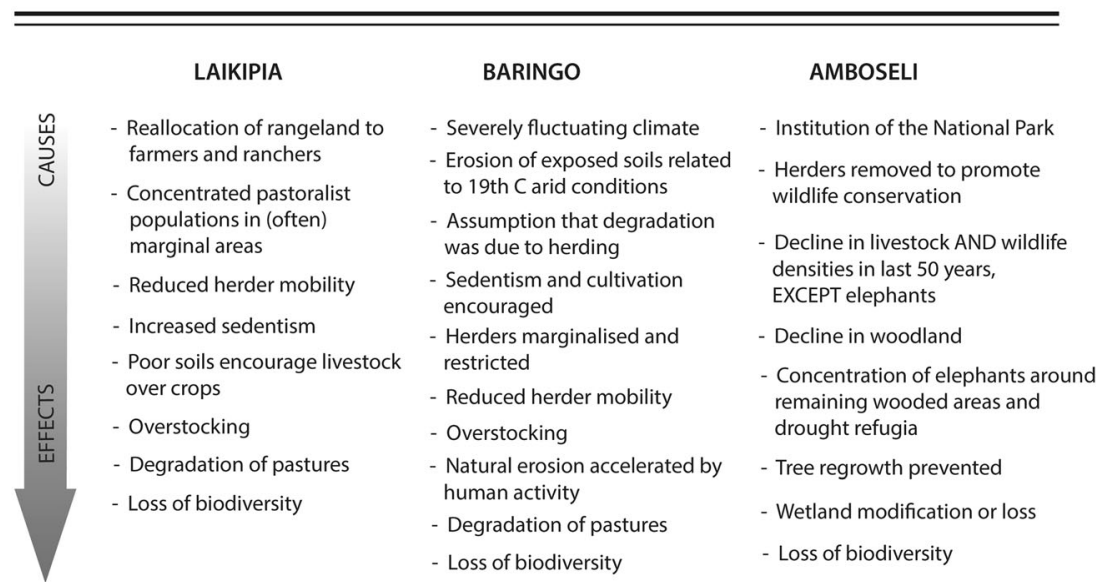

controlled by drought and disease, making overgrazing unlikely (Sullivan and Rohde 2002). Overall, there is growing acceptance that ecosystems can fluctuate between equilibrium and non-equilibrium dynamics (Briske et al. 2003; Vetter 2005).

Periodic deficits in forage are therefore unavoidable in semi-arid savannah ecosystems, and pastoralists have developed strategies to cope with such challenges. Mobility is embraced to maximize production in areas that have spatially and temporally uneven resource distributions (Western 1982; Shetler 2007). Livestock breeds favoured by pastoralists in highly seasonal and drought prone rangelands are able to adjust physiologically to food and water deprivation (Nkedianye et al. 2011). In anticipation of stock losses, large herd owners can also distribute their animals more widely to those with whom they have kin and non-kin alliances as a form of insurance or 'risk-pooling' (Aktipis et al. 2011). Pastoralists strategically manage their herds and model their livelihoods around ecosystems where losses are to be predicted. In this sense, large herds built up over good seasons are a way of storing surplus reserves to be used in poor seasons. During good times milk yields can be relied upon for sustenance, but under stressful conditions milk production falls and people consume their animals to reduce stocking rates and to meet dietary requirements, ultimately improving the health of the herd. After severe droughts, when continued offtake has reduced the rate of herd recovery, the rapid metabolic rate and milk response of cattle during realimentation is of importance, favouring dairy- rather than meat-based pastoral production strategies (Western and Finch 1986). Pastoralists in droughtprone parts of eastern Africa therefore maintain large herds that are managed for their ability to produce milk over meat and for their capacity to withstand periodic grazing deficits. Temporary participation in non-pastoralist economies and economic re-distributions also allow individuals who have taken large herd losses to re-enter herding following catastrophic losses (Shetler 2007). Pastoralists in Laikipia, Baringo, and Amboseli have all seen these strategies and their potential effectiveness severely curtailed: land divisions have restricted mobility and disrupted risk-pooling networks, and a lack of resources encourages overstocking in order to 
maximise milk production, with consequent negative impacts on herd and ecosystem health.

\section{Ecologies of Herding}

The notion that pastoralists are environmentally irresponsible and stand in opposition to rangeland conservation goals has been challenged for several decades (e.g., Ellis and Swift 1988; Warren 1995; Homewood 2008; Reid 2012). That livestock and wildlife are incompatible is contradicted by evidence that the presence of wildlife enhances cattle performance (survival, fecundity and weight-gain) and vice versa (Odadi et al. 2011). Similar arguments have been made based on studies of soil nutrient and seed redistribution linked to pastoralist activity. Cycles of daytime grazing and nightly corralling lead to concentrations of nutrients and seeds within temporary settlement sites that repel animals like elephants and which persist as 'glades' in savannah landscapes (e.g., Reid and Ellis 1995; Young et al. 1995; Veblen 2013; Fig. 6). The particular species that are represented within glades varies widely and appears dependent on highly specific local ecological conditions. While nutrient rich grasses are a common feature, species differ through space and time. Porensky and Veblen (2015), for example, observe high densities of Cynodon plectostachyus within glades in central Laikipia, yet this species was not recorded by Young et al.
Fig. 6 The possible impacts and outcomes of pastoralist settlement activity in savannah landscapes in eastern Africa. Photographs (P. Lane) show aerial view of Maasai settlement and degrading houses within an abandoned settlement, both in Amboseli
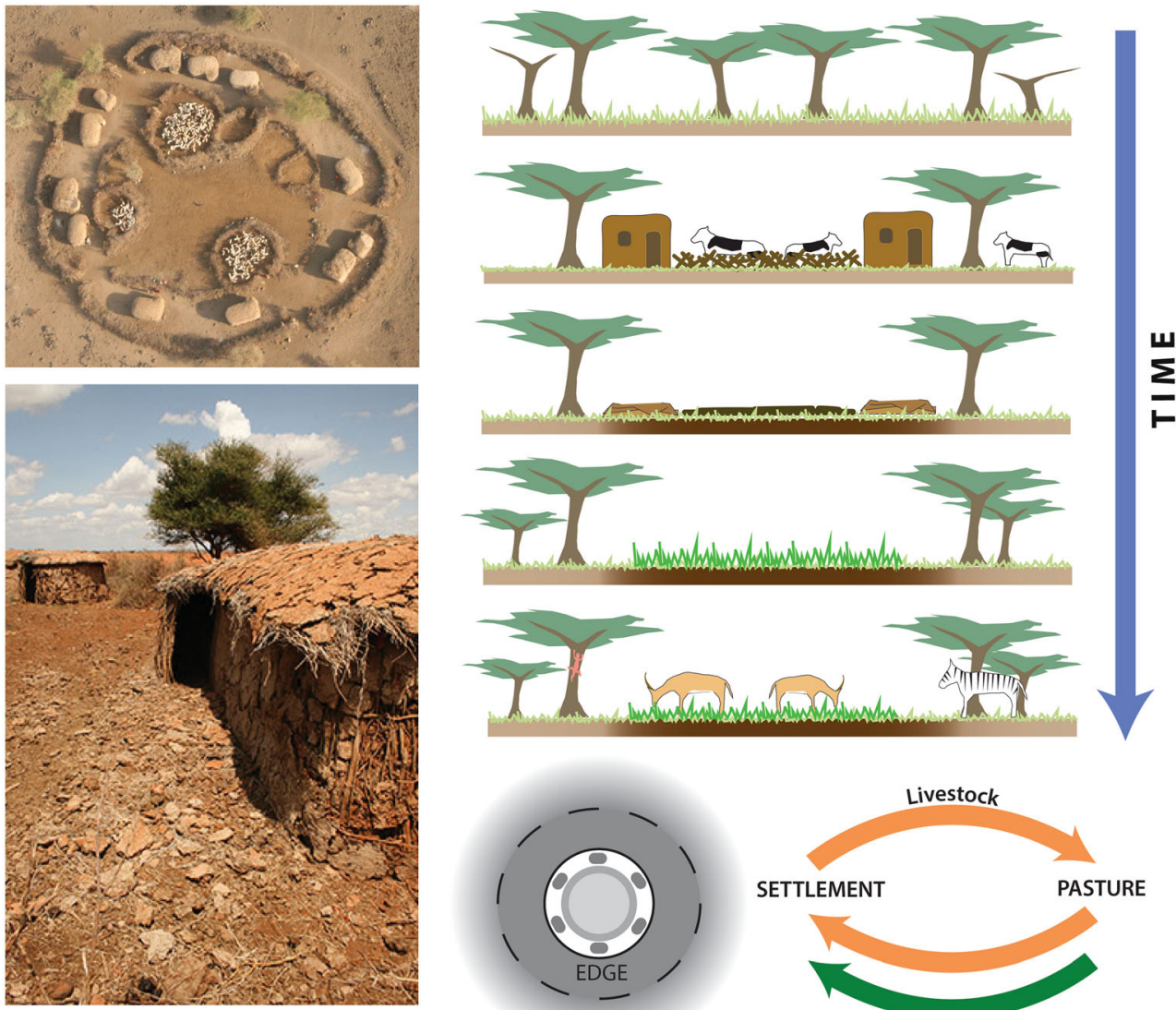
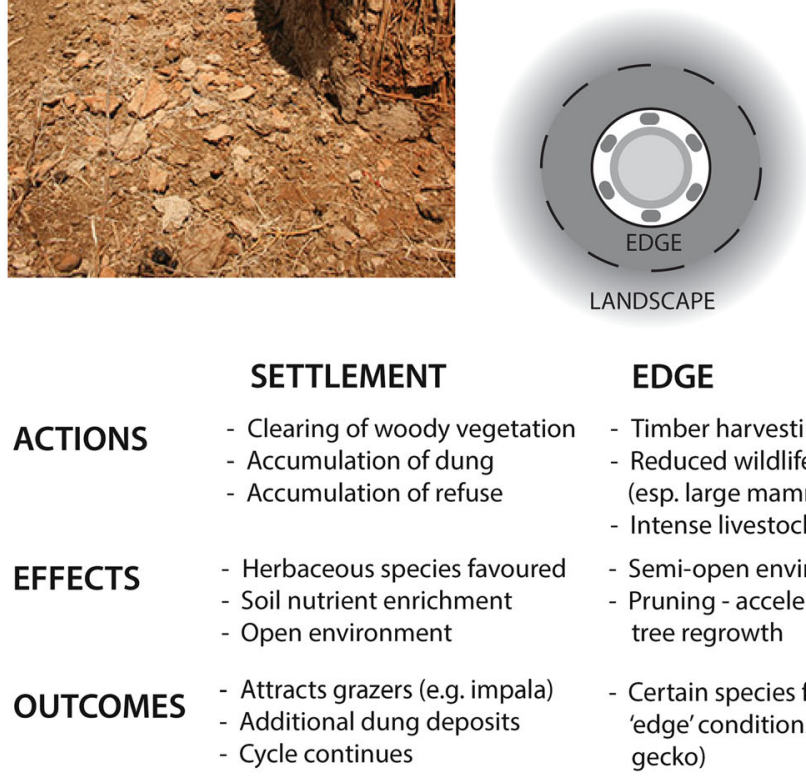

EDGE

\section{SETTLEMENT}

Clearing of woody vegetation

Accumulation of dung

- Timber harvesting - Reduced wildlife numbers (esp. large mammals) - Intense livestock grazing

- Semi-open environment - Pruning-accelerated tree regrowth

- Certain species favour 'edge' conditions (e.g. zebra, gecko)

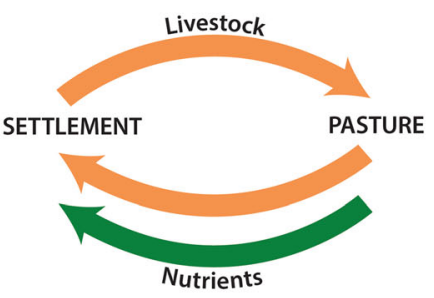

LANDSCAPE

- Light grazing

- Burning

- Reduced biomass

- Nutrient redistribution

- Seed redistribution

- Reduced pests

- Reduced risk of large fires

- Ecological heterogeneity

- Increased biodiversity 
(1995) when working in the same area; instead, Digitaria milanjiana was found to dominate. In Botswana, Cenchrus ciliaris is strongly associated with Iron Age pastoralist settlements (Denbow 1979), yet elsewhere in southern Africa, such locations host anomalous concentrations of woody taxa like Vachellia (Acacia) tortilis within a Burkea africana-dominated background (Blackmore et al. 1990). A similar pattern observed in northern Kenya is attributed to the transport and deposition of acacia seeds in the dung of browsefeeding livestock (Reid and Ellis 1995).

As distinct 'patches' within a wider savannah mosaic, glades encourage habitat heterogeneity with associated beneficial consequences for biodiversity (Young et al. 2018); rich grasses attract wild grazers (e.g., Augustine 2004), while edge effects ensure that their influence extends beyond the perimeter of former herder settlements (Young et al. 1995; Cadenasso et al. 2003). In addition, many pastoralists utilise controlled burning in order to promote grazing resources, with wider ecological implications. In woody savannah areas on the eastern edge of Amboseli, controlled seasonal burning by pastoralist communities reduces overall biomass and prevents hotter fires that damage trees (Kamau and Medley 2014). A co-benefit of anthropogenic burning is the reduction of disease vector-harbouring habitats through burning, reported across eastern Africa (Shetler 2007; Butz 2009; Kamau and Medley 2014). This has a similar effect to synthetic acaricides used to combat tick-borne infection of livestock and exercises a positive impact on biodiversity by reducing transmission to wild animal populations (Goodenough et al. 2017).

Most of the data generated and cited in support of these counter-arguments to narratives of declination are based on contemporary observation; questions remain over how best to access and integrate the longer-term dynamics of herderrangeland interaction in present day ecological syntheses and rangeland management policy. Rangeland health is linked to more than simply rainfall and stocking densities, but rather is shaped by the cumulative (i.e., long-term) effects of how resource access and use is regulated (see also Lambin et al. 2001). Equally, socio-cultural processes must be considered alongside environmental drivers and legacies. It is further important to acknowledge that while this paper is highly focused on livestock rearing aspects of pastoral production systems, pastoral livelihoods have long incorporated diverse pursuits such as cultivation, iron-production, hunting and fishing, the impacts of which cannot be overlooked when investigating East African ecologies through time (Shoemaker 2018). The entanglement (sensu Lane 2016) of cultural, political, economic, and environmental dynamics is such that singledisciplinary approaches to issues like overgrazing are inadequate and prone to motivated reasoning.

Concepts of carrying capacity - the maximal population (e.g., of livestock) an ecosystem can support, beyond which productivity declines - and equilibrium have been instrumental in shaping management plans that would avoid overgrazing on a year-by-year basis. However, they are more challenging to understand from an archaeological or palaeoecological perspective. Conservation management generally focuses on the shortterm, decadal-scale effects of pastoralism and human occupation, and can be limited to a single species (see Solbraa 2002). This level of specificity is not usually available to the palaeosciences. There is no clear method for identifying overgrazing in palaeoenvironmental proxy records, where generally only long-term consequences of certain actions are visible. At the Ngorongoro Crater Conservation Area, Tanzania, for example, pastures were observed to be overgrazed in terms of unsustainable livestock densities, yet without exhibiting conspicuous symptoms of long-term degradation (Homewood and Rodgers 1987) - i.e., the transformative changes that might be visible on the centennial and millennial scales that archaeologists and palaeoecologists generally work with.

\section{Overgrazing and the Historical Record}

In order to be identifiable in the historical record, the effects of overgrazing must constitute environmental or socio-cultural change at a scale sufficient to leave recognisable traces. Archaeologically, ecological degradation might lead to changes in hunting and herding patterns or a reduction of livestock densities, perhaps evident in zooarchaeological assemblages, or depopulation and significant change in settlement patterns. Geological and palaeoecological traces might include increased soil erosion (possibly resulting from bare grounds), reduced water infiltration into soils and increased runoff, damage to soil seed-banks, reduced grass cover and increased bush encroachment, expansion of niches and thus increased chances of species-invasiveness, reduction of coprophilic fungal spores, biogeochemical signals, and a general reduction of biomass and faunal and floral diversity. However, these must also be distinguished from the effects of non-anthropogenic drivers such as climate change.

In the historical sciences, overgrazing is more closely connected to degradation and ideas of thresholds or tipping points than in rangeland ecology or conservation (Mysterud 2006). Due to the nature of archaeological and palaeoecological data, overgrazing is more likely to be evaluated as a longer-term process with long lasting environmental and social effects leading to irreversible environmental change and degradation. Wright (2017), for example, argues that the emergence of pastoralism in the Sahara may have breached an ecological 'tipping point' that contributed to the abrupt termination of the African Humid Period (deMenocal et al. 2000). Wright's hypothesis explicitly avoids monocausal explanations for regime shifts, contending that an ecosystem already under stress and close to the 'precipice' of change might be triggered in response to new, external dynamics such as overgrazing (see Scheffer and Carpenter 2003). Various models trace steadily 
decreasing precipitation and increasingly xeric conditions following the Holocene Climate Optimum at c. 8200 BP, while contemporaneous pollen records point to swift transitions from grass- to shrub-dominated taxa seemingly coeval with archaeological evidence for the emergence and spread of stock-keeping. Indeed, a significant increase in the number of radiocarbon-dates from archaeological sites across the Sahara indicates rapid population expansion around the same time (Manning and Timpson 2014). Wright (2017: 9) attributes the vegetation change, albeit provisionally, to anthropogenic fire suppression and livestock grazing. An increase in albedo commensurate with such an ecological shift has been modelled to affect monsoon flow to the extent required for the observed drop in rainfall (Claussen and Gayler 1997).

Wright (2017) offers a persuasive synthesis of the climatic, ecological and demographic evidence for anthropogenic landscape change and its broader consequences, supported by more recent historical observations from New Zealand and North America where the introduction of domestic livestock by Europeans demonstrably impacted vegetation regimes. However, at a basic level, it is difficult to accept that the functional ecology of colonial European stock-keeping should be analogous to mid-Holocene herding in the Sahara. Moreover, given the scale of the region that was opening up - i.e., the breadth of the Sahara - pastoralist population densities and livestock counts were likely to have been relatively low during the early phases of domestication, even during the apparent demographic peak at c. 7500 BP (Manning and Timpson 2014). As is clear from our case studies, the degree of overgrazing required to exceed ecological regime transitions can often be linked to restrictions placed on pastoral mobility, itself akin to a self-policing mechanism that negates excessive exploitation of a single resource area (Krätli et al. 2013; see also Butt 2010). It seems unlikely that early Saharan herders were forcibly restricted in their movements. Indeed, the scholars on whose data Wright's hypothesis is based suggest a very different scenario: that the spread of pastoralism may in fact have increased vegetation biomass and prolonged the 'Green Sahara' (Brierley et al. 2018).

Studies like Wright's (2017) - whose findings we cannot entirely discount, even if they can be refuted - reinforce the importance of minimising generalisation and incautious analogy when exploring past human-environment relationships. Such research demands approaches that combine archaeological and palaeoenvironmental data framed by detailed understandings of ecology, ethnography, and history, and how they are entangled (Gillson and Marchant 2014; Marchant and Lane 2014). Though the principal generator of knowledge of the human past, archaeology is beholden to draw on lessons from other disciplines if its interpretations are to maintain accuracy and retain relevance. Likewise, palaeoenvironmental research should incorporate empirical data relating to land cover and land use (e.g., sedimentology, charcoal, fungal spores) in combination with spatial ethnography (e.g., Shetler 2007), historical mapping, and remote sensing. However, for integration to be successful, geochronological constraints and chronological and metrical uncertainties in all datasets need to be clearly presented and interpretive caveats clarified (e.g., Trachsel and Telford 2017).

In some cases, experimental work on the inclusion and exclusion of fire and herbivory (wild and domestic) can inform and be used to test historical research questions as well as modern land management or savannah rehabilitation (e.g., Riginos et al. 2012; Young et al. 2018). Anthropogenic glades and their associated ecological effects - such as localised soil enrichment (e.g., Muchiru et al. 2009) - have been shown to persist for centuries and are thus viable subjects for archaeological investigation (e.g., Boles and Lane 2016; Marshall et al. 2018). Such analyses might be refined through experimental work to differentiate between the specific drivers of local glade formations. Co-location of archaeological and palaeoenvironmental studies can also lead to stronger narratives of long-term human-environment interactions and each can support the limitations of the other (e.g., Taylor et al. 2005; Marchant et al. 2018).

Advances in GPS-tracking technology provide means to explore herding strategies and livestock grazing behaviour at high spatial and temporal resolutions (Coppolillo 2000; Butt 2010; Liao et al. 2018). Integrating empirical mapping data with knowledge of social, historical, and ecological contexts presents a more complex and variable picture of pastoralist livelihoods, one that brings into question models of past land use constructed using immutable typologies (e.g., mobile, semi-mobile, sedentary, or pastoral vs. agro-pastoral) and deterministic parameters like resource locations (Liao et al. 2018). Rather, production systems are shown to be influenced by dynamic relationships between diverse ecological and socio-cultural factors that vary through time. That such variation should be significant even at relatively short-term seasonal and intra-annual scales furthers the argument for the development and integration of historical data. Again, this complexity and dynamism highlights the need for subtler interpretations of herding strategies in the archaeological record using diverse datasets rather than reconstructions based on formulaic conceptual models.

\section{Conclusions}

Our case studies offer strong support to the argument that adaptive mobility is key to the ecological resilience of both pastoralist livelihoods and rangeland ecosystems. As tourismled conservation and rapid urbanisation dominate land politics in eastern Africa, the pattern of pastoral-marginalisation that began with British colonialism (see Neumann 2002; Hughes 2006) has continued, with herders being denied access to 
historic rangelands, often with direct citation of overgrazing and misuse (Brockington 1999; Brockington and Homewood 2001). This has had severe consequences not only for the herders themselves (Msoffe et al. 2011) but also for the ecosystems from which they are excluded. Certainly, vegetation is extremely quick to change in the absence of cultural controls. In the Masol Plains northwest of Lake Baringo, for example, there was a $26 \%$ increase in bushland area and a $25 \%$ decrease in grassy areas over a period of 5 years between 1973 and 1978 when the Pokot abandoned the plains due to interethnic conflict (Conant 1982). In the case of state-supported evictions from wildlife reserves, lack of foresight in the planning process has sometimes deleteriously impacted the biodiversity of ecosystems that land-managers had sought to prioritise (e.g., Bhola et al. 2012; Veldhuis et al. 2019).

The scale of the ecological footprint of pastoralism is exemplified in a study undertaken in the Iremito region of Amboseli (Western and Dunne 1979). Nine new Maasai settlements were established within $157 \mathrm{~km}^{2}$ between 1969 and 1970; assuming an impact radius of $225 \mathrm{~m}$ and allowing for a $68 \%$ resettlement rate - i.e., the re-use of previously occupied locations - over a century, it was predicted that almost $25 \%$ of the total area - nearly $40 \mathrm{~km}^{2}$ - would be directly affected (Muchiru et al. 2009). Given the millennial timescales over which pastoralism has been present in African ecosystems, its potential consequences for shaping savannah ecologies is vast. However, pastoralism comes in many forms throughout its history and there is a pressing need to move beyond normative models of pastoralists' behaviour and impact if we are to understand their interactions with rangeland ecosystems. Heterogeneity is central to the functioning of these systems, which the curtailment of pastoralist and wildlife mobility, observed in our case studies, threatens to further homogenise and weaken.

The examples of Laikipia, Baringo, and Amboseli illustrate how damaging and unsustainable levels of grazing can frequently be attributed to external pressures such as conflict, restrictions on mobility, and the cascade effects of nongrazing resource exploitation. In Laikipia, the imposition of physical boundaries and the effective ghettoisation of smallscale herders in densely-stocked group ranches has seen those pastures suffer, while large landowners with fewer stock have seen biodiversity increases; similarly, in the early-to-midtwentieth century restrictions were placed on herders in Baringo in order to limit their 'degradative' impact, only to increase pressures on an already relatively unproductive area; the contraction of rangelands in Amboseli and constriction of migratory wild animals to isolated zones and corridors has dramatically altered local ecologies, yet here again pastoralists have traditionally shouldered much of the blame. We do not expect that this degree of specificity can always be extracted from the historical archives that archaeologists and palaeoecologists work with, yet such alternative explanations force us to think beyond 'overgrazing' in our interpretations of past and present transformations of rangelands.

Acknowledgements The background research for this paper has been supported by a variety of funding bodies, all of whom are warmly thanked here: Initial research in Laikipia was undertaken under the auspices of Kenya Research Permit MOEST 13/014 issued by the Ministry of Education to PL. The archaeological surveys and excavations between 2002 and 2005 were funded by the British Academy, under the BIEA's Landscape and Environmental Change in Semi-Arid Regions of Eastern and Southern Africa - Developing Interdisciplinary Approaches project. Follow-up excavations and survey work in 2010 were undertaken as part of the Historical Ecologies of East African Landscapes (HEEAL) project funded by a European Union Marie Curie Excellence grant (MEXT-CT2006-042704) awarded to PL. OB was permitted to undertake research in Laikipia by the National Commission for Science, Technology and Innovation (NACOSTI), Kenya (permit no. NACOSTI/P/14/5093/383). This contributed to $\mathrm{PhD}$ research supported by the Arts and Humanities Research Council and UCL Graduate School. Research by NP-S, AS, and CCM was supported as part of the European Commission Marie Skłodowska-Curie Initial Training Network titled Resilience in East African Landscapes (REAL) FP7-PEOPLE-2013-ITN, project number 606879 awarded to PL. CCM's work was also supported by the Adaptation \& Resilience to Climate Change (ARCC) in Eastern Africa project funded by the Swedish Research Council (Vetenskapsrådet), Formas and the Swedish International Development and Cooperation Agency (SIDA), grant number 2016-06355 awarded to PL and AE. Research by OB, AS, CCM, and NP-S, was conducted under the following research permit numbers NACOSTI/P/14/5093/383, NACOSTI/P/ 15/4357/3327, NACOSTI/P/14/6965/1096, NACOSTI/P/14/7542/2843, respectively. We also wish to thank all other collaborators on these projects, our numerous field assistants, local hosts and community interlocutors for facilitating and enabling the research and their enduring hospitality and goodwill. Particular thanks are due to the staff of the British Institute in Eastern Africa for logistical and other support over the years, and equipment loans and provision of field vehicles; as well as partners at the National Museums of Kenya, Nairobi. ASTER L1B data used in Fig. 2 are distributed by the Land Processes Distributed Active Archive Center (LP DAAC), located at the U.S. Geological Survey (USGS) Center for Earth Resources Observation and Science (EROS) http://lpdaac.usgs.gov. We are grateful to the editors of Human Ecology and our various reviewers for their insightful comments and support in seeing this paper through to publication.

\section{Compliance with Ethical Standards}

Conflict of Interest The authors declare they have no conflict of interest.

Open Access This article is distributed under the terms of the Creative Commons Attribution 4.0 International License (http:// creativecommons.org/licenses/by/4.0/), which permits unrestricted use, distribution, and reproduction in any medium, provided you give appropriate credit to the original author(s) and the source, provide a link to the Creative Commons license, and indicate if changes were made.

\section{References}

Aktipis, C. A., Cronk, L., and de Aguiar, R. (2011). Risk-Pooling and Herd Survival: An Agent-Based Model of a Maasai Gift-Giving System. Human Ecology 39(2): 131-140. 
Altmann, J. (1998). Foraging for Survival: Yearling Baboons in Africa, University of Chicago Press, Chicago.

Anderson, D. M. (2002). Eroding the Commons: The Politics of Ecology in Baringo, Kenya 1890-1963, James Currey, Oxford.

Anderson, D. M., and Bollig, M. (2016). Resilience and Collapse: Histories, Ecologies, Conflicts and Identities in the BaringoBogoria Basin, Kenya. Journal of Eastern African Studies 10(1): 1-20.

Archambault, C. S. (2016). Re-creating the Commons and Reconfiguring Maasai Women's Roles on the Rangelands in the Face of Fragmentation. International Journal of the Commons 10(2): 728-746. https://doi.org/10.18352/ijc.685.

Ashley, G. M., Maitima Mworia, J., Muasya, A. M., Owen, R. B., Driese, S. G., Hover, V. C., Renaut, R. W., Goman, M. F., Mathai, S., and Blatt, S. H. (2004). Sedimentation and recent history of a freshwater wetland in a semi-arid environment: Loboi Swamp, Kenya, East Africa. Sedimentology 51(6): 1301-1321.

Augustine, D. J. (2004). Influence of Cattle Management On Habitat Selection by Impala on Central Kenyan Rangeland. Journal of Wildlife Management 68(4): 916-923.

Becker, M., Alvarez, M., Heller, G., Leparmarai, P., Maina, D., Malombe, I., Bollig, M., and Vehrs, H. P. (2016). Land-Use Changes and the Invasion Dynamics of Shrubs in Baringo. Journal of Eastern African Studies 10(1): 111-129.

Bessems, I., Verschuren, D., Russell, J. M., Hus, J., Mees, F., and Cumming, B. F. (2008). Palaeolimnological evidence for widespread late 18th century drought across equatorial East Africa. Palaeogeography, Palaeoclimatology, Palaeoecology 259(2-3): $107-120$.

Bhola, N., Ogutu, J. O., Piepho, H. P., Said, M. Y., Reid, R. S., Hobbs, N. T., and Olff, H. (2012). Comparative Changes in Density and Demography of Large Herbivores in the Masai Mara Reserve and its Surrounding Human-Dominated Pastoral Ranches in Kenya. Biodiversity and Conservation 21(6): 1509-1530.

Blackmore, A. C., Mentis, M. T., Scholes, R. J. (1990). The origin and extent of nutrient-enriched patches within a nutrient-poor savanna in South Africa. Journal of Biogeography 17(4/5): 463-470.

Blake, W., Rabinovich, A., Wynants, M., Kelly, C., Nasseri, M., Ngondya, I., Patrick, A., Mtei, K., Munishi, L., Boeckx, P., and Navas, A. (2018). Soil Erosion in East Africa: An Interdisciplinary Approach to Realising Pastoral Land Management Change. Environmental Research Letters 13: 124014. https://doi.org/10. 1088/1748-9326/aaea8b.

Boles, O. J. C., and Lane, P. J. (2016). The Green, Green Grass Of Home: An Archaeo-Ecological Approach to Pastoralist Settlement in Central Kenya. Azania: Archaeological Research in Africa 51(4): 507-530.

Bollig, M. (2016). Adaptive cycles in the savannah: Pastoral Specialization and Diversification in Northern Kenya. Journal of Eastern African Studies 10(1): 21-44.

Bollig, M., and Österle, M. (2013). The political ecology of specialisation and diversification: Long-term dynamics of pastoralism in east Pokot District, Kenya. In Bollig, M., Schnegg, M., and Wotzka, H.-P. (eds.), Pastoralism in Africa: Past, Present and Future, Berghahn, Oxford, pp. 289-315.

Bond, J. (2015). Making sense of Human-Elephant Conflict in Laikipia County, Kenya. Society \& Natural Resources 28(3): 312-327.

Brierley, C., Manning, K., and Maslin, M. (2018). Pastoralism may have Delayed the End of the Green Sahara. Nature communications 9(1): 4018.

Briske, D. D., Fuhlendorf, S. D., and Smeins, F. E. (2003). Vegetation Dynamics on Rangelands: A Critique of the Current Paradigms. Journal of Applied Ecology 40(4): 601-614.

Brockington, D. (1999). Conservation, Displacement and Livelihoods. The Consequences of the Eviction for Pastoralists Moved from the Mkomazi Game Reserve, Tanzania. Nomadic Peoples 3(2): 74-96.
Brockington, D., and Homewood, K. (2001). Degradation Debates and Data Deficiencies: The Mkomazi Game Reserve, Tanzania. Africa 71(3): 449-480.

Brown, L. H. (1971). The Biology of Pastoral Man as a Factor in Conservation. Biological Conservation 3(2): 93-100.

BurnSilver, S. (2009). Pathways of continuity and change: Maasai livelihoods in Amboseli, Kajiado District, Kenya. In Homewood, K. M., Kristjanson, P., and Chenevix Trench, P. (eds.), Staying Maasai? Livelihoods, Conservation and Development in East African Rangelands, Springer, New York, pp. 161-208.

Butt, B. (2010). Seasonal Space-Time Dynamics of Cattle Behavior and Mobility Among Maasai Pastoralists in Semi-arid Kenya. Journal of Arid Environments 74(3): 403-413.

Butz, R. J. (2009). Traditional Fire Management: Historical Fire Regimes and Land Use Change in Pastoral East Africa. International Journal of Wildland Fire 18(4): 442-450.

Cadenasso, M. L., Pickett, S. T., Weathers, K. C., Jones, C. G. (2003). A framework for a theory of ecological boundaries. AIBS Bulletin 53(8): 750-758.

Caughley, G. (1979). What is this thing called carrying capacity? In Boyce, M. S., and Hayden-Wing, L. D. (eds.), North American Elk: Ecology, Behavior and Management, The University of Wyoming, Laramie, pp. 2-8.

Chamaillé-Jammes, S., Fritz, H., Valeix, M., Murindagomo, F., and Clobert, J. (2008). Resource Variability, Aggregation and Direct Density Dependence in an Open Context: The Local Regulation of an African Elephant Population. Journal of Animal Ecology 77: $135-144$.

Chapman, A. (1908). On Safari: Big-Game Hunting in British East Africa, Edward Arnold, London.

Claussen, M., and Gayler, V. (1997). The Greening of the Sahara During the Mid-Holocene: Results of an Interactive Atmosphere-Biome Model. Glob. Ecol. Biogeogr. Lett. 6: 369-377. https://doi.org/10. 2307/2997337.

Conant, F. P. (1982). Thorns paired, sharply recurved: Cultural controls and rangeland quality in East Africa. In Spooner, B., and Mann, H. S. (eds.), Desertification and Development: Dryland Ecology in Social Perspective, Academic Press, London, pp. 111-122.

Coppolillo, P. B. (2000). The Landscape Ecology of Pastoral Herding: Spatial Analysis of Land Use and Livestock Production in East Africa. Human Ecology 28(4): 527-560.

Croze, H., and Lindsay, W. K. (2011). Amboseli ecosystem context: Past and present. In Moss, C. J., Croze, H., and Lee, P. C. (eds.), The Amboseli Elephants: A Long-Term Perspective on a Long-Lived Animal, University of Chicago Press, Chicago, pp. 11-28.

Davis, D. K. (2004). Desert 'Wastes' of the Maghreb: Desertification Narratives in French Colonial Environmental History of North Africa. Cultural Geographies 11(4): 359-387.

De Beer, Y., Kilian, W., Versfeld, W., and Van Aarde, R. J. (2006). Elephants and Low Rainfall Alter Woody Vegetation in Etosha National Park, Namibia. Journal of Arid Environment 64: 412-421.

De Cort, G., Bessems, I., Keppens, E., Mees, F., Cumming, B., and Verschuren, D. (2013). Late-Holocene and Recent hydroclimatic Variability in the Central Kenya Rift Valley: The Sediment Record of Hypersaline Lakes Bogoria, Nakuru and Elementeita. Palaeogeography, Palaeoclimatology, Palaeoecology 388: 69-80.

De Cort, G., Verschuren, D., Ryken, E., Wolff, C., Renaut, R. W., Creutz, M., Van Der Meeren, T., Haug, G., Olago, D. O., and Mees, F. (2018). Multi-Basin Depositional Framework for MoistureBalance Reconstruction During the Last 1300 Years at Lake Bogoria, Central Kenya Rift Valley. Sedimentology. https://doi. org/10.1111/sed.12442.

deMenocal, P., Ortiz, J., Guilderson, T., Adkins, J., Sarnthein, M., Baker, L., and Yarusinsky, M. (2000). Abrupt Onset and Termination of the African Humid Period: Rapid Climate Responses to Gradual Insolation Forcing. Quaternary Science Reviews 19(1): 347-361. 
Denbow, J. (1979). Cenchrus ciliaris: An Ecological indicator of Iron Age Middens Using Aerial Photography in Eastern Botswana. South African Journal of Science 75(9): 405-408.

Dundas, K. R. (1910). Notes on the Tribes Inhabiting the Baringo District, East Africa Protectorate. The Journal of the Royal Anthropological Institute of Great Britain and Ireland 40: 49-72.

Dunne, T., Dietrich, W. E., and Brunengo, M. J. (1978). Recent and Past Erosion Rates in Semi-arid Kenya. Zeitschrift für Geomorphologie 29: $130-140$.

Ellis, J. E., and Swift, D. M. (1988). Stability of African Pastoral Ecosystems: Alternate Paradigms and Implications for Development. Journal of Range Management 41(6): 450-459.

Evans, L. A., and Adams, W. M. (2016). Fencing Elephants: The hidden Politics of Wildlife Fencing in Laikipia, Kenya. Land Use Policy 51: $215-228$

Galaty, J. G. (2016). Reasserting the Commons: Pastoral Contestations of Private and State Lands in East Africa. International Journal of the Commons 10(2): 709-727. https://doi.org/10.18352/ijc.720.

Gilbert, H. (2013). 'Bedouin overgrazing' and conservation politics: Challenging ideas of pastoral destruction in South Sinai. Biological Conservation 160: 59-69.

Gillson, L., and Marchant, R. (2014). From myopia to clarity: Sharpening the focus of ecosystem management through the lens of palaeoecology. Trends in Ecology \& Evolution 29(6): 317-325.

Githumbi, E., Kariuki, R., Shoemaker, A., Courtney Mustaphi, C., Chuhila, M., Richer, S., Lane, P., and Marchant, R. (2018a). Pollen, People and Place: Paleoenvironmental, Archaeological, and Ecological Perspectives on Vegetation Change in the Amboseli Landscape, Kenya. Frontiers in Earth Science 5 Article 113: 1-26. https://doi.org/10.3389/feart.2017.00113.

Githumbi, E. N., Courtney Mustaphi, C. J., Yun, K. J., Muiruri, V., Rucina, S. M., and Marchant, R. (2018b). Late Holocene Wetland Transgression and 500 Years of Vegetation and Fire Variability in the Semi-arid Amboseli landscape, southern Kenya. Ambio 47(6): 682-696. https://doi.org/10.1007/s13280-018-1014-2.

Goodenough, A. E., Harrell, A. N., Keating, R. L., Rolfe, R. N., Stubbs, H., MacTavish, L., and Hart, A. G. (2017). Managing Grassland for Wildlife: The effects of Rotational Burning on Tick Presence and Abundance in African Savannah Habitat. Wildlife Biology: wlb00318.

Groom, R. J., and Western D. (2013). Impact of land subdivision and sedentarization on wildlife in Kenya's southern rangelands. Rangeland Ecology and Management 66: 1-9.

Grove, R. (1996). Green Imperialism: Colonial Expansion, Tropical Island Edens and the Origins of Environmentalism, Cambridge University Press, Cambridge, pp. 1600-1860.

Hardin, G. (1968). The Tragedy of the Commons. Science 162: $1243-1248$.

Hein, L. (2006). The Impacts of Grazing and Rainfall Variability on the Dynamics of a Sahelian Rangeland. Journal of Arid Environments 64: $488-504$

Herskovits, M. J. (1926). The Cattle Complex in East Africa. American Anthropologist 28(1): 230-272.

Homewood, K. (2008). Ecology of African Pastoralist Societies, James Currey, Oxford.

Homewood, K. M., and Rodgers, W. A. (1987). Pastoralism, conservation and the overgrazing controversy. In Anderson, D. M., and Grove, R. (eds.), Conservation in Africa: People, Policies, and Practice, Cambridge University Press, Cambridge, pp. 111-128.

Homewood, K. M., Trench, P. C., and Brockington, D. (2012). Pastoralist Livelihoods and Wildlife Revenues in East Africa: A case for Coexistence? Pastoralism: Research, Policy and Practice 2(1): 19.

Huber, M., and Opondo, C.J. (1995). Land Use Change Scenarios for Subdivided Ranches in Laikipia District, Kenya (LaikipiaMount Kenya Reports 19). Institute of Geography, University of Berne, Berne.
Hughes, L. (2006). Moving the Maasai: A Colonial Misadventure, Palgrave Macmillan, Basingstoke.

Huho, J. M., Ngaira, J. K., and Ogindo, H. O. (2010). Drought Severity and their Effects on Rural Livelihoods in Laikipia District, Kenya. Journal of Geography and Regional Planning 3(3): 35-43.

Iaccino, L. (2017). What's behind the violence in Kenya's Laikipia region? Newsweek, [online], Available at http://www.newsweek.com/ kenya-kuki-gallmann-drought-violence-laikipia-590617 [Accessed 21 December 2017]

Kamau, P. N., and Medley, K. E. (2014). Anthropogenic Fires and Local Livelihoods at Chyulu Hills, Kenya. Landscape and Urban Planning 124: 76-84.

Kiage, L. M. (2013). Perspectives on the Assumed Causes of Land Degradation in the Rangelands of Sub-Saharan Africa. Progress in Physical Geography 37(5): 664-684.

Köhler, T. (1987). Land use in transition: aspects and problems of small scale farming in a new environment: the example of Laikipia District, Kenya. Geographical Society, Berne.

Kramm, J. (2015). Das Bewässerungsdispositiv: staatliche Strategien, lokale Praktiken und politisierte Räume in Kenia (Vol. 10). Bielfeld, [transcript] Verlag.

Krätli, S., Huelsebusch, C., Brooks, S., and Kaufmann, B. (2013). Pastoralism: A Critical Asset for Food Security Under Global Climate Change. Animal frontiers 3(1): 42-50.

Lambin, E. F., Turner, B. L., Geist, H. J., Agbola, S. B., Angelsen, A., Bruce, J. W., Coomes, O. T., Dirzo, R., Fischer, G., Folke, C., and George, P. (2001). The Causes of Land-Use and Land-Cover Change: Moving Beyond the Myths. Global Environmental Change 11(4): 261-269.

Lane, P. J. (2011). An Outline of the Later Holocene Archaeology and Precolonial History of the Ewaso Basin, Kenya. Smithsonian Contributions to Zoology (632): 11-30.

Lane, P. J. (2015). Sustainability: Primordial conservationists, environmental sustainability and the rhetoric of pastoralist cultural heritage in East Africa. In Rico, T., and Lafrenz Samuels, K. (eds.), Heritage Keywords: Rhetoric and Redescription in Cultural Heritage, University Press of Colorado, Boulder, pp. 259-283.

Lane, P. J. (2016). Entangled banks and the domestication of east African pastoralist landscapes. In Fernandini, F., and Der, L. (eds.), Archaeology of entanglement, Left Coast Press, Walnut Creek, pp. $127-150$.

Letai, J. (2011). Land deals in Kenya: The genesis of land deals in Kenya and its implication on pastoral livelihoods - a case study of Laikipia District, 2011. In International Conference on Global Land Grabbing, Brighton, UK, pp. 6-8.

Lewis, A.E. (2015). Amboseli Landscapes: Maasai Pastoralism, Wildlife Conservation, and Natural Resource Management in Kenya, 1944Present. Dissertation submitted to Michigan State University.

Liao, C., Clark, P. E., Shibia, M., and DeGloria, S. D. (2018). Spatiotemporal Dynamics of Cattle Behavior and Resource Selection Patterns on East African Rangelands: Evidence from GPS-tracking. International Journal of Geographical Information Science. https://doi.org/10.1080/13658816.2018.1424856.

Lindsay, W. K. (1989). Integrating parks and pastoralists: Some lessons from Amboseli. In Anderson, D. M., and Grove, R. H. (eds.), Conservation in Africa: People, Policies, and Practice, Cambridge University Press, Cambridge, pp. 149-168.

Lindsay, W. K. (2011). Habitat use, diet choice, and nutritional status in female and male Amboseli elephants. In Moss, C. J., Croze, H., and Lee, P. C. (eds.), The Amboseli Elephants: A Long-Term Perspective on a Long-Lived Mammal, University of Chicago Press, Chicago, pp. 51-73.

Little, P. D. (1992). The Elusive Granary: Herder, Farmer, and State in Northern Kenya, Cambridge University Press, Cambridge. 
Little, P. D. (1996). Pastoralism, Biodiversity, and the Shaping of Savanna Landscapes in East Africa. Journal of the International African Institute 66(1): 37-51.

Livingstone, I. (1991). Livestock Management and "Overgrazing" Among Pastoralists. Ambio 20(2): 80-85.

Manning, K., and Timpson, A. (2014). The Demographic Response to Holocene Climate Change in the Sahara. Quaternary Science Reviews 101(C): 28-35.

Marchant, R., and Lane, P. (2014). Past Perspectives for the Future: Foundations for Sustainable Development in East Africa. Journal of Archaeological Science 51: 12-21.

Marchant, R., Richer, S., Boles, O. J. C., Capitani, C., Courtney Mustaphi, C. J., Lane, P. J., Prendergast, M. E., Stump, D., De Cort, G., Kaplan, J. O., Phelps, L., Kay, A. U., Olago, D. O., Petek, N., Platts, P. J., Punwong, P., Widgren, M., Wynne-Jones, S., Ferro-Vázquez, C., Benard, J., Boivin, N. L., Crowther, A., Cuní-Sanchez, A., Deere, N. J., Ekblom, A., Farmer, J., Finch, J. M., Fuller, D. Q., Gaillard-Lemdahl, M.-J., Gillson, L., Githumbi, E. N., Kabora, T., Kariuki, R., Kinyanjui, R. N., Kyazike, E., Lang, C., Lejju, J., Morrison, K. D., Muiruri, V. M., Mumbi, C., Muthoni, R., Muzuka, A., Ndiema, E., Kabonyi Nzabandora, C., Onjala, I., Pas Schrijver, A., Rucina, S. M., Shoemaker, A. C., Thornton-Barnett, S., van der Plas, G., Watson, E. E., Williamson, D., and Wright, D. K. (2018). Drivers and Trajectories of Land Cover Change in East Africa: Human and Environmental Interactions from 6000 Years Ago to Present. Earth-Science Reviews 178: 322-378.

Marshall, F., Reid, R. E., Goldstein, S., Storozum, M., Wreschnig, A., Hu, L., Kiura, P., Shahack-Gross, R., and Ambrose, S. H. (2018). Ancient Herders Enriched and Restructured African Grasslands. Nature 561(7723): 387-390.

Mizutani, F. (1999). Biomass Density of Wild and Domestic Herbivores and Carrying Capacity on a Working Ranch in Laikipia District, Kenya. African Journal of Ecology 37(2): 226-240.

Morrison, T. A., Holdo, R. M., and Anderson, T. M. (2016). Elephant Damage, Not Fire or Rainfall, Explains Mortality of Overstorey Trees in Serengeti. Journal of Ecology 104(2): 409-418.

Moss, C. J. (2001). The demography of an African elephant (Loxodonta africana) population in Amboseli, Kenya. Journal of Zoology 255(2): 145-156.

Msoffe, F. U., Kifugo, S. C., and Said, M. Y. (2011). Drivers and Impacts of Land-Use Change in the Maasai Steppe of Northern Tanzania: An Ecological, Social and Political Analysis. Journal of Land Use Science 6(4): 261-281.

Muchiru, A. N., Western, D., and Reid, R. S. (2009). The Impact of Abandoned Pastoral Settlements on Plant and Nutrient Succession in an African Savanna Ecosystem. Journal of Arid Environments 73(3): 322-331.

Mysterud, A. (2006). The Concept of Overgrazing and its role in Management of Large Herbivores. Wildlife Biology 12(2): 129-141.

Neumann, R. P. (2002). Toward a critical theorization of conservation enclosures. In Peet, R., and Watts, M. (eds.), Liberation Ecologies: Environment, Development and Social Movements, Routledge, London, pp. 179-199.

Nkedianye, D., de Leeuw, J., Ogutu, J. O., Said, M. Y., Saidimu, T. L., Kifugo, S. C., Kaelo, D. S., and Reid, R. S. (2011). Mobility and Livestock Mortality in Communally Used Pastoral Areas: The Impact of the 2005-2006 Drought on Livestock Mortality in Maasailand. Pastoralism: Research, Policy and Practice 1(1): 17.

Odadi, W., Karachi, M. K., Abdulrazak, S. A., and Young, T. P. (2011). African Wild Ungulates Compete with or Facilitate Cattle Depending on Season. Science 333: 1753-1755.

Ogutu, J. O., Piepho, H. P., Said, M. Y., and Kifugo, S. C. (2014). Herbivore Dynamics and Range Contraction in Kajiado County Kenya: Climate and Land Use Changes, Population Pressures,
Governance, Policy and Human-Wildlife Conflicts. The Open Ecology Journal 7: 9-31.

Ogutu, J. O., Piepho, H. P., Said, M. Y., Ojwang, G. O., Njino, L. W., Kifugo, S. C., and Wargute, P. W. (2016). Extreme Wildlife Declines and Concurrent Increase in Livestock Numbers in Kenya: What are the Causes? PloS one 11(9): e0163249.

Pas Schrijver, A. (2019). Pastoralists, Mobility and Conservation: Shifting Rules of Access and Control of Grazing Resources in Kenya's Northern Drylands, Department of Human Geography, University of Stockholm, Stockholm.

Paterson, I. D., Hoffmann, J. H., Klein, H., Neser, S., Mathenge, C. W., and Zimmermann, H. G. (2011). Biological control of cactaceae in South Africa. African Entomology, 19(1): 230-246.

Perier, J.-A.-N. (1847). Exploration scientifique de l'Algerie: sciences médicales vol I, Imprimerie Royale, Paris.

Petek, N. (2018). Archaeological Perspectives on Risk and Community Resilience in the Baringo Lowlands, Kenya. Studies in Global Archaeology 24. Uppsala: Uppsala University.

Petek, N., and Lane, P. (2017). Ethnogenesis and Surplus Food Production: Communitas and Identity Building Among Nineteenth- and Early Twentieth-Century Ilchamus, Lake Baringo, Kenya. World Archaeology 49: 40-60.

Porensky, L. M., and Veblen, K. E. (2015). Generation of Ecosystem Hotspots Using Short-Term Cattle Corrals in an African Savanna. Rangeland Ecology and Management 68(2): 131-141.

Powell-Cotton, P. H. G. (1904). Unknown Africa: A Narrative of Twenty Months' Travel and Sport in Unknown Lands and Among New Tribes, Hurst and Blackett, London.

Reid, R. S. (2012). Savannas of Our Birth: People, Wildlife, and Change in East Africa, University of California Press, Los Angeles.

Reid, R. S., and Ellis, J. E. (1995). Impacts of Pastoralists on Woodlands in South Turkana, Kenya: Livestock- Mediated Tree Recruitment. Ecological Applications 5(4): 978-992.

Republic of Kenya. (1984). Baringo Pilot Semi Arid Area Project. Ministry of Agriculture, Nairobi.

Riginos, C., Porensky, L. M., Veblen, K. E., Odadi, W. O., Sensenig, R. L., Kimuyu, D., Keesing, F., Wilkerson, M. L., and Young, T. P. (2012). Lessons on the Relationship Between Livestock Husbandry and Biodiversity from the Kenya Long-Term Exclosure Experiment (KLEE). Pastoralism: Research, Policy and Practice 2(1): 10.

Rutten, M. M. E. M. (1992). Selling wealth to buy poverty: The process of individualization of land ownership among the Maasai pastoralists of Kajiado District, Kenya. Verlag Breitenbach Publishers, Saarbrucken.

Scheffer, M., and Carpenter, S. R. (2003). Catastrophic Regime Shifts in Ecosystems: Linking Theory to Observation. Trends in Ecology and Evolution 18(12): 648-656.

Shanahan, M. (2016). Media perceptions and portrayals of pastoralists in Kenya, India and China. In The End of Desertification, Springer, Berlin, Heidelberg, pp. 407-425.

Shetler, J. B. (2007). Imagining Serengeti: A History of Landscape Memory in Tanzania from Earliest Times to the Present, Ohio University Press, Columbus.

Shoemaker, A. (2018). Pastoral pasts in the Amboseli landscape: An archaeological exploration of the Amboseli ecosystem from the later Holocene to the colonial period. Uppsala University, Uppsala.

Solbraa, K. (2002). Veiledning i elgbeitetaksering. Skogbrukets Kursinstitutt, Honne, Biri.

Spinage, C.A. (2012). African Ecology: Benchmarks and historical Perspectives. Springer-Verlag, Berling.

Stafford Smith, M. (1996). Management of rangelands: Paradigms at their limits. In Hodgson, J., and Illius, A. (eds.), The Ecology and Management of Grazing Systems, CABI, Wallingford, pp. 325-357.

Strum, S. C., Stirling, G., and Mutunga, S. K. (2015). The Perfect Storm: Land Use Change Promotes Opuntia stricta's Invasion of Pastoral Rangelands in Kenya. Journal of Arid Environments 118: 37-47. 
Sullivan, S., and Rohde, R. (2002). On Non-equilibrium in Arid and Semi-arid Grazing Systems. Journal of Biogeography 29: $1595-1618$.

Sundaresan, S. R., and Riginos, C. (2010). Lessons Learned from Biodiversity Conservation in the Private Lands Of Laikipia, Kenya. Great Plains Research 20: 17-27.

Taiti, S.W. (1992). The Vegetation of Laikipia District Kenya. Laikipia Research Programme, Nanyuki, Baseline Papers B-2.

Taylor, D., Lane, P. J., Muiruri, V., Ruttledge, A., McKeever, R. G., Nolan, T., Kenny, P., and Goodhue, R. (2005). Mid-to LateHolocene Vegetation Dynamics on the Laikipia Plateau, Kenya. The Holocene 15(6): 837-846.

Thomson, J. (1885). Through Masai Land: A Journey of Exploration Among the Snowclad Volcanic Mountains and Strange Tribes of Eastern Equatorial Africa. Sampson, Low, Marston, Searle, \& Rivington, London.

Trachsel, M., and Telford, R. J. (2017). All Age-Depth Models are Wrong, but are Getting Better. The Holocene 27(6): 860-869.

Vaughan, C. (2005). Changing patterns of land-use during the colonial era. In Lane, P. J. (ed.), Landscape and Environmental Change in Semi-Arid Regions of East \& Southern Africa: Developing Interdisciplinary Approaches, Unpublished Report, British Institute in Eastern Africa, pp. 12-26.

Veblen, K. E. (2013). Impacts of Traditional Livestock Corrals on Woody Plant Communities in an East African Savanna. The Rangeland Journal 35(3): 349-353.

Vehrs, H.-P., and Heller, G. R. (2017). Fauna, Fire, and Farming: Landscape Formation over the Past 200 years in Pastoral East Pokot, Kenya. Human Ecology 45(5): 613-625.

Veldhuis, M. P., Ritchie, M. E., Ogutu, J. O., Morrison, T. A., Beale, C. M., Estes, A. B., Mwakilema, W., Ojwang, G. O., Parr, C. L., Probert, J., and Wargute, P. W. (2019). Cross-boundary Human Impacts Compromise the Serengeti-Mara Ecosystem. Science 363(6434): 1424-1428.

Vetter, S. (2005). Rangelands at Equilibrium And Non-equilibrium: Recent Developments in the Debate. Journal of Arid Environments 62(2): 321-341.

von Höhnel, L. (1892). Zum Rudolph-See un Stephanie-See. Die Forschungsreise des Grafen Samuel Teleki in Ost-AequatorialAfrika 1887-1888, Wilfred Gölder, Vienna.

Waller, R. D. (1988). Emutai: crisis and response in Maasailand. In Johnson, D. H., and Anderson, D. M. (eds.), The Ecology of Survival: Case Studies from Northeast Africa, Left Coast Press, Walnut Creek, pp. 127-150.

Wambuguh, O. (2007). Interactions Between Humans and Wildlife: Landowner Experiences Regarding Wildlife Damage, Ownership and Benefits in Laikipia District, Kenya. Conservation and Society 5(3): 408-428.
Warren, A. (1995). Changing Understandings of African Pastoralism and the Nature of Environmental Paradigms. Transactions of the Institute of British Geographers, New Series 20(2): 193-203.

Western, D. (1975). Water Availability and its Influence on the Structure and Dynamics of a Savannah Large Mammal Community. East African Wildlife Journal 13: 265-286.

Western, D. (1982). Amboseli National Park: Enlisting Landowners to Conserve Migratory Wildlife. Ambio 11(5): 302-308.

Western, D., and Dunne, T. (1979). Environmental Aspects of Settlement Site Decisions Among Pastoral Maasai. Human Ecology 7(1): 75-98.

Western, D., and Finch, V. (1986). Cattle and Pastoralism: Survival and Production in Arid Lands. Human Ecology 14(1): 77-94.

Western, D., and Maitumo, D. (2004). Woodland Loss and Restoration in a Savannah Park: A 20-Year Experiment. African Journal of Ecology 42(2): 111-121.

Western, D., Groom, R., and Worden, H. (2009). The Impact of Subdivision and Sedentarization of Pastoral Lands on Wildlife in an African Savanna Ecosystem. Biological Conservation 142: 2538-2546.

Western, D., Mose, V. N., Worden, J., and Maitumo, D. (2015). Predicting Extreme Droughts in Savannah Africa: A Comparison of Proxy and Direct Measures in Detecting Biomass Fluctuations, Trends and Their Causes. PloS One 10(8): e0136516.

Wiens, J. A. (1977). On Competition and Variable Environments. American Scientist 65(5): 590-597.

Wright, D. K. (2017). Humans as Agents in the Termination of the African Humid Period. Frontiers in Earth Science 5: PA4203PA4214.

Young, T. P., Patridge, N., and Macrae, A. (1995). Long-Term Glades in Acacia Bushland and Their Edge Effects in Laikipia, Kenya. Ecological Applications 5(1): 97-108.

Young, T. P., Porensky, L. M., Riginos, C., Veblen, K. E., Odadi, W. O., Kimuyu, D. M., Grace, G. K., and Young, H. S. (2018). Relationships Between Cattle and Biodiversity in Multiuse Landscape Revealed by Kenya Long-Term Exclosure Experiment. Rangeland Ecology \& Management 71(3): 281-291.

Yurco, K. (2017). Herders and Herdsmen: The Remaking Of Pastoral Livelihoods in Laikipia, Kenya. Pastoralism 7(1): 15.

Zerboni, A., and Nicoll, K. (2018). Enhanced Zoogeomorphological Processes in North Africa in the Human-Impacted Landscapes Of the Anthropocene. Geomorphology. https://doi.org/10.1016/j. geomorph.2018.10.011.

Publisher's Note Springer Nature remains neutral with regard to jurisdictional claims in published maps and institutional affiliations. 